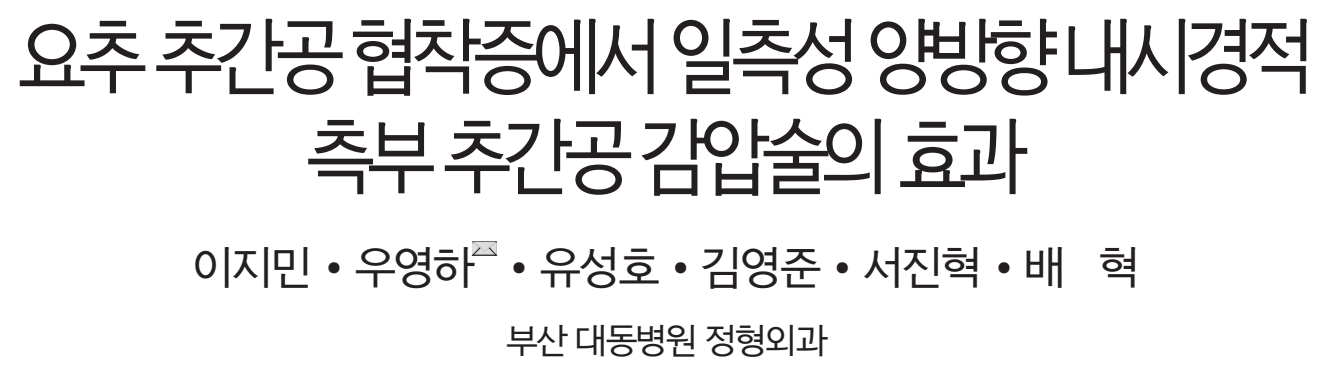

\title{
Efficacy of Unilateral Biportal Endoscopic Decompression in Lumbar Foraminal Stenosis
}

\author{
Ji-Min Lee, M.D., Young-Ha Woo, M.D. ${ }^{\star}$, Seong-Ho Yoo, M.D., Young-Jun Kim, M.D., \\ Jin-Hyuk Seo, M.D., and Hyuk Bae, M.D. \\ Department of Orthopedic Surgery, Daedong Hospital, Busan, Korea
}

\begin{abstract}
Purpose: This paper reports the short-term clinical and radiological results of unilateral biportal endoscopic decompression (UBE) to prove its efficacy.

Materials and Methods: Twenty patients who received unilateral biportal endoscopic far-lateral decompression (UBEFLD) were analyzed statistically using the visual analogue scale (VAS), modified Macnab criteria and Oswestry Disability Index (ODI) clinically. Radiologically, their intervertebral angle (IVA), percentage slip, disc height index (DHI) and foraminal height index (FHI) were analyzed pre- and postoperatively.

Results: The VAS scores were 6.20 preoperatively, which improved to 2.05, 1.75 and 1.45 at postoperative one month, three months and one year, respectively $(p<0.001)$. The modified macnab criteria in both the good or excellent category was $70.0 \%, 80.0 \%$ and $85.0 \%$ at postoperative one month, three months and one year, respectively ( $p=0.034$ ). The ODI improved from $59.8 \%$ preoperatively to $35.8 \%, 33.2 \%$, and $17.1 \%$ at postoperative one month, three months, and one year, respectively $(p<0.001)$. The IVA was increased $0.40 \pm 0.88$ after a surgery $(p=0.057)$. Percentage slip was increased $0.19 \%$ after surgery $(p=0.134)$. The $\mathrm{DHI}$ changed from 0.49 preoperatively to 0.62 postoperatively $(p=0.359)$, and the FHI changed from 0.71 preoperatively to 0.79 postoperatively $(p<0.001)$.
\end{abstract}

Conclusion: UBEFLD displayed satisfactory results. Such a result highlights the potential of UBEFLD as an excellent alternative to spinal fusion or microscopic surgery.

Key words: lumbar spine, foraminal stenosis, unilateral biportal decompression, efficacy

\section{서 론}

추간공 협착증은 좁아진 추간공으로 인한 신경근 압박을 유발하 여 요통, 방사통, 감각이상 등의 증상을 보이는 질환이다. 유병률

\footnotetext{
Received July 18, 2019 Revised October 10, 2019 Accepted November 8, 2019

Correspondence to: Young-Ha Woo, M.D.

Department of Orthopedic Surgery, Daedong Hospital, 187 Chungnyeol-daero, Dongnae-gu, Busan 47737, Korea

TEL: +82-51-554-1233 FAX:+82-51-553-7575 E-mail: woo0ha@naver.com ORCID: https://orcid.org/000-0002-3102-7260
}

은 8\%- $11 \%$ 로 신경근통이 지속되는 퇴행성 척추관절 질환을 않 고 있는 환자의 치료에 반드시 고려해야 할 질환으로 판단된다. ${ }^{1)}$ 추간공 협착증은 보존적 치료로 $70 \%$ 에서 증상의 유지, 약 $15 \%$ 에 서 증상의 악화, 나머지 $15 \%$ 에서 증상의 호전을 보인다. ${ }^{2)}$ 이처럼 보존적 치료에서 한계를 보이고 환자군의 연령증가로 인한 최근 수술적 치료의 빈도가 높아지고 있다. 종래의 고식적 수술법인 척추관절 완전 절제술 및 유합술은 최대한의 신경근 감압 효과를 보여주나 분절 불안정증, 요추부 통증, 인접분절의 퇴행성 변화 와 같은 단점들이 부각되어 주변조직의 손상을 최소화하는 최소 
Ji-Min Lee, et al.

침습 수술법이 각광받고 있다. 이에 현미경을 이용한 수술이 시 행되어 왔으며 최근에는 내시경을 이용한 수술법이 도입되어 사 용되고 있다. ${ }^{2,3)}$ 이러한 흐름에 맞춰 본 연구에서는 양방향 내시 경적 감압술의 수술 술기 및 임상적, 영상학적 결과를 보고하고 자 한다.

\section{대상및 방법}

연구 대상자는 2016년 5월부터 2019년 4월 사이 요추 추간공

Table 1. Demographic Characteristics

\begin{tabular}{|c|c|}
\hline Variable & Value \\
\hline No. of patients & 20 \\
\hline Male & 12 \\
\hline Female & 8 \\
\hline Age (yr) & $63.05(42-87)$ \\
\hline Mean follow-up duration (mo) & $12(8-14)$ \\
\hline Diagnosis (lumbar foraminal stenosis) & 20 \\
\hline No. of decompression levels (UBE) & 1 level; 20 patients \\
\hline Decompressed disc level & 20 \\
\hline L3-L4 & 4 \\
\hline L4-L5 & 11 \\
\hline L5-S1 & 5 \\
\hline
\end{tabular}

Values are presented as number only or mean (range). UBE, unilateral biportal endoscopic decompression.

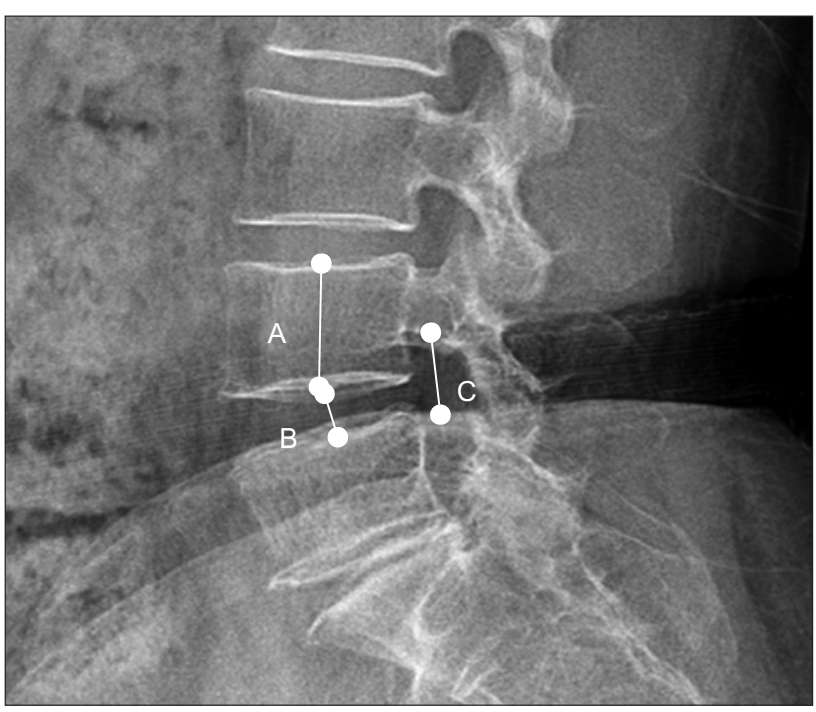

Figure 1. Description of disc height index (DHI) and foraminal height index (FHI). DHI: B/A; FHI: C/A. A, vertebral height at the midpoint of the body; $B$, disc height at the midpoint of the disc; $C$, foraminal height measured as the largest distance.
협착증으로 인하여 일측성 양방향 내시경적 측부 추간공 감압술 을 시행한 20 명에 해당한다(Table 1). 모든 수술은 1 명의 술자가 담당하였으며, 임상적으로 시각통증척도(visual analogue scale, VAS), modified Macnab criteria, oswestry disability index (ODI), 영상학적으로 disc height index (DHI), foraminal height index (FHI), percentage slip, intervertebral angle (IVA) 결과를 술 전, 술 후에 나누어 분석하였다(Fig. 1, 2). 모든 통계는 IBM SPSS ver. 18.0 (IBM Corp., Armonk, NY, USA)을 사용하여 분석하였다. 결과값은 평균과 표준편차로 표현하였으 며 환자군은 t-test를 통해 분석하였다. 0.05 미만의 p값은 통계 적으로 유의한 것으로 판단하였다.

\section{1. 수술준비}

환자를 방사선 투과성 수술대 위에 복와위(prone position)로 위 치시킨다. 환자의 두경부와 상체는 허리높이보다 아래에 위치시 켜 출혈을 최소화하고 수축기 혈압을 90-100 mmHg 이상 유지 하였다. $4.0 \mathrm{~mm}$ 0도와 30도 시야의 관절경을 준비하였으며 전 기 소작기, 캐리슨 펀치(Kerrison punch), 면도기(shaver), 소파 기(curet), 고속 골 절삭기(high speed burr) 등의 고식적 척추 수술 기구들을 사용하였다. 자연 중력식 생리식염수 펌프를 환자 50-60 cm 상부에 위치시킨다.

\section{2. 횡돌기 골단면 (basecamp)의 시야확보} 수술 부위 소독 이후 내시경 카메라 진입과 지속적인 관류를 위

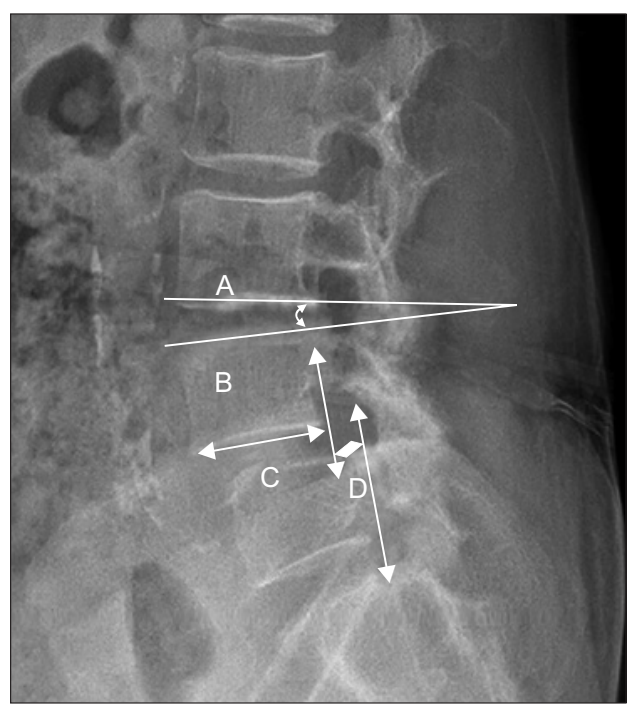

Figure 2. Description of intervertebral angle (IVA) and percentage slip. IVA: degree between $A$ and $B$; slip percentage (\%): (D/C)×100. A, upper vertebra lower margin; $B$, lower vertebra upper margin; $C$, upper vertebra lower margin; $D$, distance between post. Margin of the two vertebra body. 
한 관찰 삽입구(viewing portal)와 감압술을 위한 기구를 삽입할 작업 삽입구(working portal)를 만든다. C-arm을 통한 해부학 적 지표는 목표 추간공의 위, 아래의 추체와 횡돌기이다. 위 추체 의 외측 경계에서 $1 \mathrm{~cm}$ 외측, 횡돌기의 상부 경계 높이에 하나의 입구(portal)를 만들고 약 $2 \mathrm{~cm}$ 원위부에 두 번째 입구를 만든다 (Fig. 3). 지속적인 생리식염수 배출 및 기구 삽입을 위해 각 삽입 구는 약 $1 \mathrm{~cm}$ 길이의 피부 절개로 충분하였다. 술자의 위치에서 좌측을 작업 삽입구, 우측을 시야를 위한 관찰 삽입구로 하였다. 작업 삽입구를 통하여 상부 척추 횡돌기 배부와 횡돌기와 이어지 는 협부(isthmus)를 근육 거상기를 사용하여 분리시키고 생리식 염수를 주사하여 충분한 술기를 위한 공간을 확보한다. 내시경의 회전 움직임만으로 혈종 배출을 유도할 수 있으며 횡돌기 골단 면의 깨끗한 시야를 확보할 수 있다. 딱딱한 근섬유들은 면도기 를 이용하여 제거하고 미세한 출혈은 전기 소작기를 이용하여 조

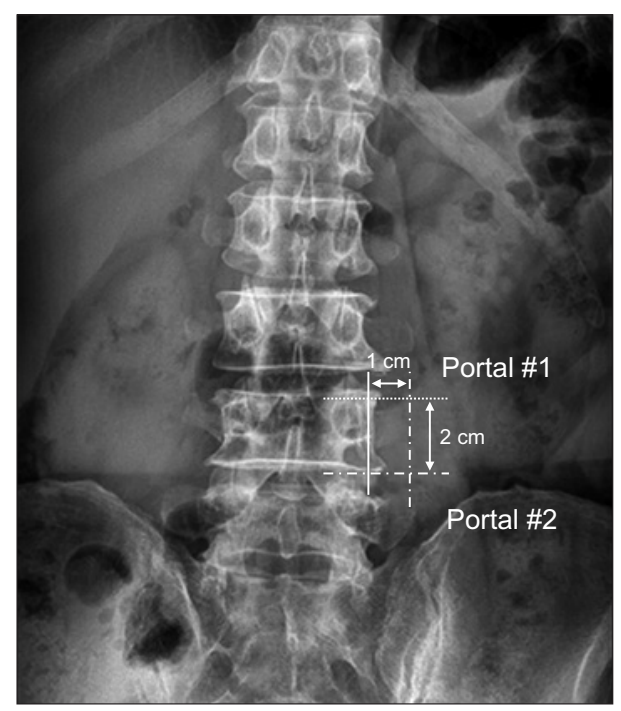

Figure 3. Anatomical landmark and portal placement of unilateral biportal endoscopic far-lateral decompression.
절한다. 충분한 생리식염수 배출을 위해 캐리슨 펀치를 사용하여 주변 피하 근육들을 분리해 주어야 한다.

\section{3. 시야와 위치인식}

내시경을 상부 척추 횡돌기에 위치시킨 이후 위치를 유지하기 위 해 추간공 자체보다는 횡돌기 원위부 경계 사이에 공간을 확보 한다. 제대로 위치하였을 경우 관절낭(capsule)과 같은 백색 연 부조직은 내시경의 12 시 방향에서 확인이 가능하다. 하부 척추 의 위쪽 관절 돌기(superior articular process, $\mathrm{SAP}$ )의 끝부분 을 노출시키기 위해 소파기를 사용하여 관절낭의 근위 변연부를 절제해야 한다. 위치 확인에 도움이 되는 다른 구조물들은 내측 에서의 추간공 입구, $\mathrm{SAP}$ 의 배부 관절하면, 횡돌기간 인대(intertransverse ligament)가 있다. 횡돌기간 인대의 전방부로 지나치 게 많이 공간확보를 시도할 경우 요근에 손상을 줄 수 있기 때문 에 주의가 필요하다.

\section{4. 추간공확공술, 황색인대 절제술, 디스크 절제술} 하부 척추의 SAP의 근위부 말단을 절제할 때는 제한된 공간 내부 에서 절제가 쉽지 않기 때문에 캐리슨 펀치 등을 사용하여 조금 씩 조각내어 제거한다. 추간공에서 황색인대 근위부는 상부 척추 횡돌기와 척추경(pedicle) 원위부 표면에서 확실하게 구분된다. 목표 구획의 황색인대 절제술을 시행할 때는 상부 척추 횡돌기 의 원위부 말단 아래로 주행하는 신경근을 손상시키지 않도록 주 의해야 한다. 신경근은 때로 상부 척추 횡돌기 하단에 숨겨져 있 거나 퇴행성 섬유성 혈관들을 위축된 신경근으로 오인할 수 있어 주의가 필요하다. 필요시 신경근 주변의 작은 혈관들의 출혈조절 후 디스크 절제술을 시도할 수 있다. 섬유륜은 indian knife로 절 제하고 소파기을 섬유륜의 외막 아래로 삽입하여 파열된 디스크 조각들을 신경근 아래에서 제거하도록 한다. 추간공의 SAP 부분 절제를 통하여 충분한 신경근의 감압이 이루어진 후 신경근 말단 과 기저부 모두에서 감압시켜 충분한 공간을 확보해야만 신경관

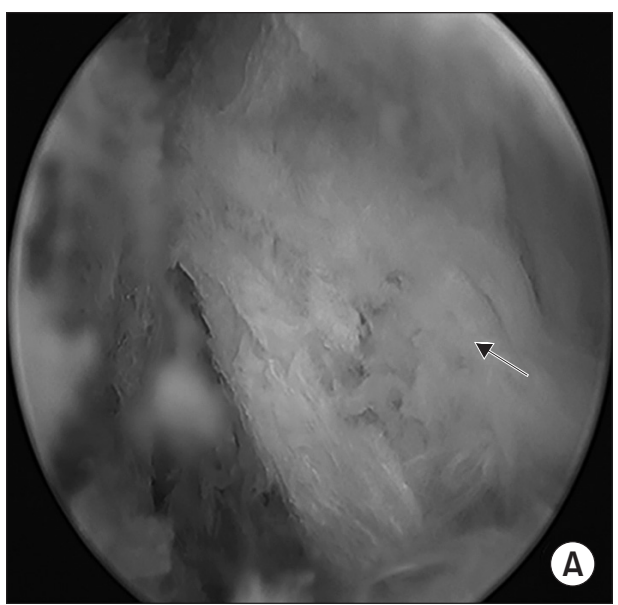

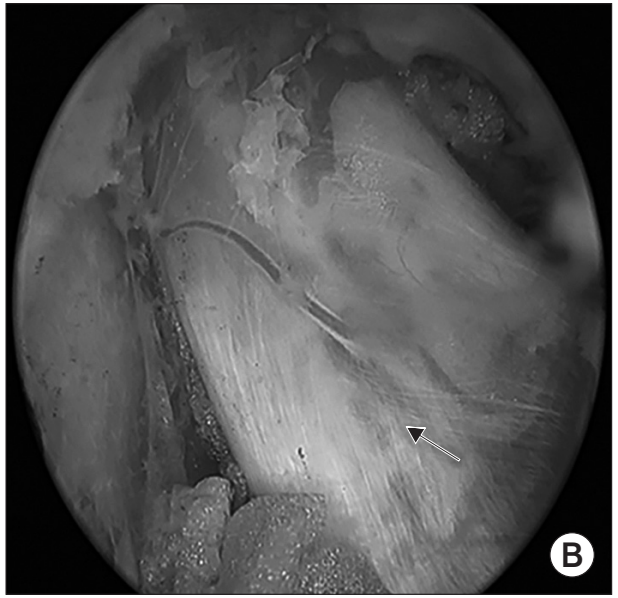

B
Figure 4. Intraoperative arthroscopic view. (A) Before foraminal decompression. Arrow indicates foraminal ligament. (B) After foraminal decompression by unilateral biportal endoscopic far-lateral decompression. Arrow indicates decompressed nerve root. 

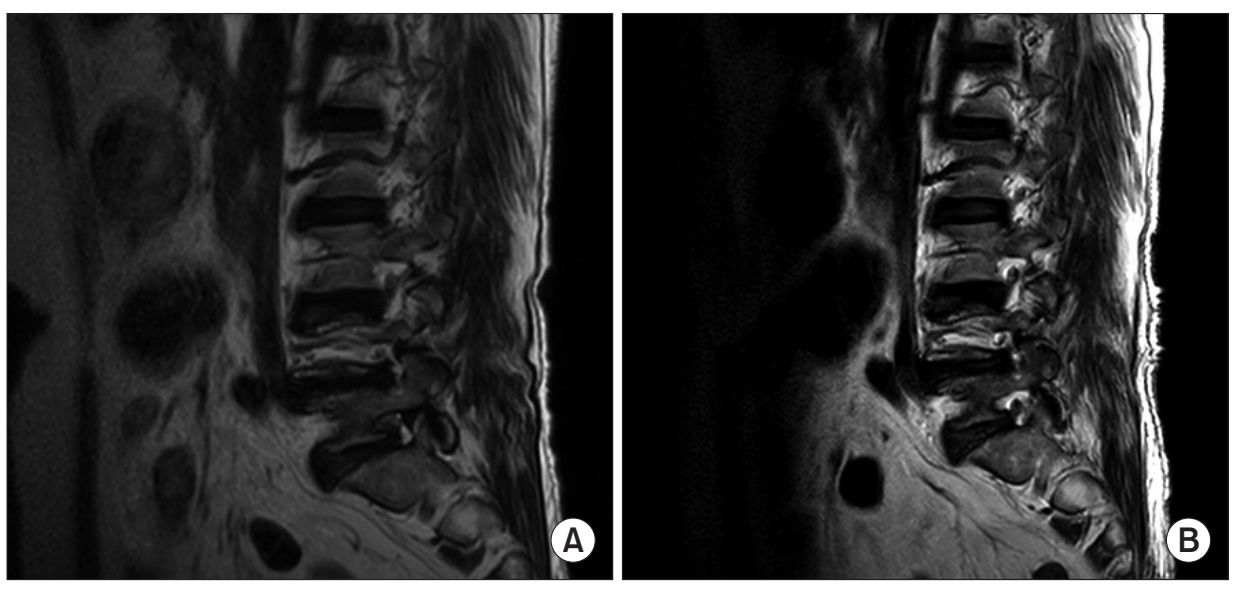

Figure 5. Preoperative and postoperative magnetic resonance imaging (MRI). (A) Preoperative MRI of lumbar foraminal stenosis L5/S1, left. (B) Postoperative MRI After foraminal decompression by unilateral biportal endoscopic far-lateral decompression.

Table 2. Clinical Outcomes of Unilateral Biportal Endoscopic Decompression (UBE)

\begin{tabular}{lcc}
\multicolumn{1}{c}{ Variable } & Value & p-value \\
VAS & & $<0.001$ \\
Preoperative & $6.20 \pm 0.52$ & \\
POD 1 wk & $2.20 \pm 0.52$ & \\
POD 1 mo & $2.05 \pm 0.39$ & \\
POD 3mo & $1.75 \pm 0.44$ & \\
POD 1yr & $1.45 \pm 0.51$ & \\
Modified Macnab score (\%) & & 0.034 \\
POD 1 wk & $55.0 \pm 51.0$ & \\
POD 1 mo & $70.0 \pm 47.0$ & \\
POD 3 mo & $80.0 \pm 41.0$ & \\
POD 1 yr & $85.0 \pm 36.6$ & \\
ODI (\%) & & $<0.001$ \\
Preoperative & $59.8 \pm 4.6$ & \\
POD 1 wk & $41.3 \pm 2.8$ & \\
POD 1 mo & $35.8 \pm 3.6$ & \\
POD 3 mo & $33.2 \pm 3.6$ & \\
POD 1 yr & $17.1 \pm 2.0$ & \\
\hline
\end{tabular}

Values are presented as mean \pm standard deviation. VAS, visual analogue scale; POD, postoperative day; ODI, Oswestry Disability Index.

협착을 막고 재협착을 방지할 수 있다(Fig. 4, 5).

\section{결 과}

\section{1. 임상적 결과}

VAS는 평균 술 전 $6.20 \pm 0.52$ 에서 술 후 1 년 $1.45 \pm 0.51$ 로 기 간이 경과함에 따라 측정치가 통계적으로 유의하게 낮아진 것으 로 나타났다(p<0.001). Modified Macnab criteria는 술 후 1
Table 3. Radiologic Outcomes of Unilateral Biportal Endoscopic Decompression (UBE)

\begin{tabular}{lllr}
\multicolumn{1}{c}{ Variable } & Preoperative & Postoperative & p-value \\
IVA $\left(^{\circ}\right)$ & $7.28 \pm 5.88$ & $7.68 \pm 5.62$ & 0.057 \\
Percentage slip (\%) & $10.0 \pm 3.6$ & $10.3 \pm 3.7$ & 0.134 \\
DHI & $0.49 \pm 0.13$ & $0.62 \pm 0.60$ & 0.359 \\
FHI & $0.71 \pm 0.17$ & $0.79 \pm 0.20$ & $<0.001$ \\
\hline
\end{tabular}

Values are presented as mean \pm standard deviation. IVA, intervertebral angle; $\mathrm{DHI}$, disc height index; FHl, foraminal height index.

년 총 $85 \%$ 의 환자들에게서 good 혹은 excellent 판정을 받았 다(p=0.034). ODI는 술 전 $59.8 \% \pm 4.6 \%$ 에서 최종 술 후 1 년 $17.10 \% \pm 2.00 \%$ 로 기간이 경과함에 따라 측정치가 통계적으로 유의하게 높아진 것으로 나타났다 $(\mathrm{p}<0.001 ;$ Table 2).

\section{2. 영상학적 결과}

$\mathrm{IVA}$ 는 술 전과 술 후 비교하여 평균 $0.40 \pm 0.88$ 도 증가 ( $\mathrm{p}=0.057$ ), percentage slip은 술 전과 술 후 비교하여 $0.2 \% \pm$ $0.6 \%$ 로 증가 $(\mathrm{p}=0.134), \mathrm{DHI}$ 는 술 전 $0.49 \pm 0.13$ 에서 술 후 0.62 \pm 0.60 으로 변화하여 $(\mathrm{p}=0.359)$ 다소 높아졌으나 통계적으로 유 의한 차이는 나타나지는 않았다. FHI는 술 전 $0.71 \pm 0.17$ 에서 술 후 $0.79 \pm 0.20$ 으로 변화하여 통계적으로 유의하게 높아진 것으 로 나타났다(p<0.001; Table 3, Fig. 6).

\section{고 찰}

양방향 내시경적 감압술은 단방향 내시경 감압술에 비하여 우수 한 시야와 다양한 수술기구의 적용가능성, 술 후 불안정성의 위 험성을 최소화하는 장점으로 최근 각광받고 있는 수술 술기이 다. ${ }^{4,5)}$

양방향 내시경적 감압술이 기존의 단방향 내시경적 감압술과 

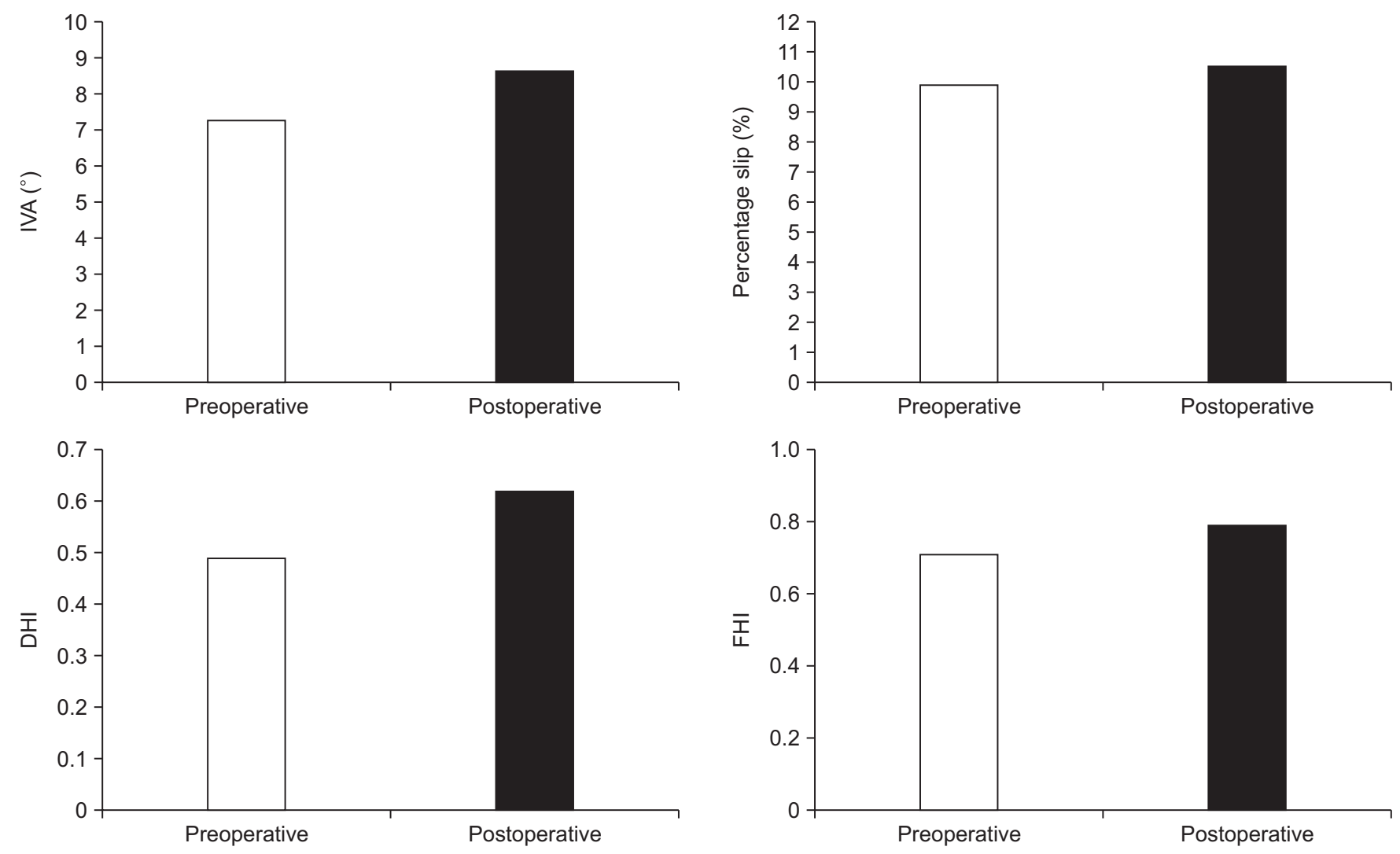

Figure 6. Radiologic outcomes of unilateral biportal endoscopic decompression (UBE). IVA, intervertebral angle; DHI, disc height index; FHI, foraminal height index.

비교하여 갖는 첫 번째 장점은 두 개의 입구를 사용함으로써 주 시야 입구를 유지하면서도 다양한 도구를 응용할 수 있기에 척추 주변 근육 등 연부조직 손상을 최소화할 수 있다는 점이다. 그리 고 단방향 술기에 비하여 관류액 배출이 원활하여 생리식염수 배 출 부족으로 인한 근육부종을 예방할 수 있다. ${ }^{0}$

두 번째 장점은 단일입구 술기에 비하여 현미경을 이용한 술 기와 동일한 다양한 크기의 수술기구의 응용을 통해 쉬운 수술 이 가능하다는 것이다. Floating scope 술기를 통해 단순한 내시 경의 회전만으로도 다양한 시야를 확보할 수 있으며 목표를 크게 확대해서 관찰할 수 있다. 출혈로 인하여 시야가 가려질 수도 있 으나 이는 해부학적 구조물을 숙지하고 push-lock 방법으로 경 막외 지혈을 신중히 시행하는 것으로 예방이 가능하다. ${ }^{1,4)}$

양방향 내시경적 감압술은 때로는 근위부와 반대측 황색인대 의 불충분한 감압을 야기하기도 한다. ${ }^{7)}$ 이에 필요시 척추돌기 상 부와 하방을 충분히 burr로 갈아내어 반대측으로부터 내시경과 기구들이 충분한 진입각을 확보할 수 있다. Angled curet을 이용 하여 층판의 하부를 충분히 긁어주는 술기도 도움이 된다. 2.8$)$

양방향 내시경적 감압술이 갖는 최대의 장점은 술 후 불안정성 을 유발하지 않는다는 사실에 있다. ${ }^{9)}$ 본 연구 결과에서는 수술 전 후 IVA, percentage slip, DHI 변화에서 모두 통계적으로 유의
미한 결과를 보이지 않았으며 FHI는 통계적으로 유의하게 높아 진 것으로 나타났으나 차이가 크지 않은 것으로 판단된다. 이는 본 환자군에서 술 후 불안정성이 발생하지 않고 향후 최소화될 가능성을 보여준다고 할 수 있다. ${ }^{10-13)}$

본 연구의 가장 큰 문제점은 수술 증례의 부족으로 인한 비교 가능한 환자군의 부재라 할 수 있다. 다른 개방적 술기에 해당하 는 동일한 집단과 비교가 가능했다면 좀 더 의미 있는 평가가 가 능했으리라 생각된다. 그리고 추시관찰 증례 또한 추후 연구에서 필요할 것이다.

\section{결 론}

추간공 협착증에서 양방향 내시경적 감압술은 기술적으로 매우 우수한 방법이다. 이번 연구에서 양방향 내시경적 감압술을 시행 받은 환자에서 술 후 환자들의 증상이 임상적으로 호전되었으며 영상학적 비교에서 수술 후 불안정성 유발에 있어 만족스러운 결 과를 보였다. 이에 양방향 내시경적 감압술은 효과적이며 안정적 인 술기로 판단되며 추간공 협착증 치료를 위한 수술에서 개방적 술기의 훌륭한 대체가 될 수 있을 것이다. 


\section{CONFLICTS OF INTEREST}

The authors have nothing to disclose.

\section{ORCID}

Ji-Min Lee, https://orcid.org/0000-0002-1291-7401

Young-Ha Woo, https://orcid.org/0000-0002-3102-7260

Seong-Ho Yoo, https://orcid.org/0000-0001-5955-4479

Young-Jun Kim, https://orcid.org/0000-0003-2684-0174

Jin-Hyuk Seo, https://orcid.org/0000-0003-4332-7903

Hyuk Bae, https://orcid.org/0000-0002-9042-5613

\section{REFERENCES}

1. Ahn JS, Lee HJ, Choi DJ, Lee KY, Hwang SJ. Extraforaminal approach of biportal endoscopic spinal surgery: a new endoscopic technique for transforaminal decompression and discectomy. J Neurosurg Spine. 2018;28:492-8.

2. Phan K, Teng I, Schultz K, Mobbs RJ. Treatment of lumbar spinal stenosis by microscopic unilateral laminectomy for bilateral decompression: a technical note. Orthop Surg. 2017;9:241-6.

3. Cavuşoğlu H, Kaya RA, Türkmenoglu ON, Tuncer C, Colak I, Aydin Y. Midterm outcome after unilateral approach for bilateral decompression of lumbar spinal stenosis: 5-year prospective study. Eur Spine J. 2007;16:2133-42.

4. Choi DJ, Kim JE, Jung JT, et al. Biportal endoscopic spine surgery for various foraminal lesions at the lumbosacral lesion. Asian Spine J. 2018;12:569-73.

5. Kim JE, Choi DJ. Bi-portal arthroscopic spinal surgery (BASS) with $30^{\circ}$ arthroscopy for far lateral approach of L5-S1 - technical note. J Orthop. 2018;15:354-8.

6. Choi CM, Chung JT, Lee SJ, Choi DJ. How I do it? Biportal endoscopic spinal surgery (BESS) for treatment of lumbar spinal stenosis. Acta Neurochir (Wien). 2016;158:459-63.

7. Eum JH, Heo DH, Son SK, Park CK. Percutaneous biportal endoscopic decompression for lumbar spinal stenosis: a technical note and preliminary clinical results. J Neurosurg Spine. 2016;24:602-7.

8. Choi DJ, Choi CM, Jung JT, Lee SJ, Kim YS. Learning curve associated with complications in biportal endoscopic spinal surgery: challenges and strategies. Asian Spine J. 2016;10:6249.

9. Kim JE, Choi DJ, Park EJ. Clinical and radiological outcomes of foraminal decompression using unilateral biportal endoscopic spine surgery for lumbar foraminal stenosis. Clin Orthop Surg. 2018;10:439-47.

10. Hsieh PC, Koski TR, O'Shaughnessy BA, et al. Anterior lumbar interbody fusion in comparison with transforaminal lumbar interbody fusion: implications for the restoration of foraminal height, local disc angle, lumbar lordosis, and sagittal balance. J Neurosurg Spine. 2007;7:379-86.

11. Chen IR, Wei TS. Disc height and lumbar index as independent predictors of degenerative spondylolisthesis in middle-aged women with low back pain. Spine (Phila Pa 1976). 2009;34:1402-9.

12. Singh V, Montgomery SR, Aghdasi B, Inoue H, Wang JC, Daubs MD. Factors affecting dynamic foraminal stenosis in the lumbar spine. Spine J. 2013;13:1080-7.

13. Alam WCA. Radiological evaluation of lumbar intervertebral instability. Ind J Aerospace Med. 2002;46:48-53. 


\section{요추 추간공협착증에서일측성 양방향내시경적 측부 추간공감압술의 효과 이지민 • 우영하 - 유성호・김영준・서진혁・배 혁 부산 대동병원 정형외과}

목적: 양방향 내시경적 감압술(unilateral biportal endoscopic decompression, UBE)의 유용성을 증명하기 위해 수술의 임상적, 영상학적 결과를 보고하고자 한다.

대상 및 방법: 요추 추간공 협착증으로 일측성 양방향 내시경적 측부 추간공 감압술(unilateral biportal endoscopic far-lateral decompression, UBEFLD)을 시행받은 20명의 환자들을 분석하였다. 임상적으로 시각통증척도(visual analogue scale, VAS), modified Macnab criteria, Oswestry Disability Index (ODI), 영상학적으로 수술 전후 단순영상을 비교하여 intervertebral angle (IVA), percentage slip, disc height index (DHI), foraminal height index (FHI)를 분석하였다.

결과: VAS는 평균적으로 술 전 6.20에서 술 후 1 개월 $2.05,3$ 개월 1.75, 1년 1.45로 호전을 보였다(p<0.001). Modified Macnab criteria는 술 후 1 개월 $70.0 \%, 3$ 개월 80.0\%, 1년 85.0\%의 환자들에서 good 혹은 excellent 판정을 받았다(p=0.034). ODI 는 술 전 59.8\%, 1개월 35.8\%, 3개월 33.2\%, 1년 17.1\%로 호전을 보였다(p<0.001). IVA는 술 후 평균 0.40도 증가(p=0.057), percentage slip은 술 후 $0.19 \%$ 증가하였다(p=0.134). DHI는 술 전 0.49에서 술 후 0.62 로 증가(p=0.359), FHI 또한 술 전 0.71 에 서 술 후 0.79 로 증가하였다 $(\mathrm{p}<0.001)$.

결론: UBEFLD는 임상학적 및 영상학적으로 모두 만족스러운 결과를 보였으며 종래의 척추 유합술이나 현미경 추간공 성형술의 훌륭한 대체가 될 수 있음을 의미한다.

색인단어: 요추, 추간공 협착증, 일측성 양방향 추간공 내시경 감압술, 효과

접수일 2019년 7월 18일 수정일 2019년 10월 10일 게재확정일 2019년 11월 8일

책임저자 우영하

47737, 부산시 동래구 충렬대로 187 , 부산대동병원 정형외과

TEL 051-554-1233, FAX 051-553-7575, E-mail woo0ha@naver.com, 0RCID https://orcid.org/0000-0002-3102-7260 